\title{
Physico-Chemical and Microbial Water Quality Assessment of Densu River of Ghana
}

\author{
A. Y. Karikari* and O. D. Ansa-Asare \\ CSIR-Water Research Institute, P. O. Box M.32, Accra, Ghana \\ * Corresponding author
}

\begin{abstract}
Water quality assessment conducted in the Densu basin of Ghana between July 2003 and March 2004 identified human, animal and agricultural activities as the main sources of pollution. The $p \mathrm{H}$ of the water was neutral $(p \mathrm{H}$ range 7.20-7.48) and was unaffected by seasonal variation. The river waters were moderately soft to slightly hard (range of hardness $91.2-111 \mathrm{mg} / \mathrm{CaCO}_{3}$ ) with high turbidity due to poor farming practices, which result in large quantities of topsoil ending up in the river after rains. High nutrient loads observed in the basin were due to domestic, agricultural and industrial activities. The waters exhibited a general ionic dominance pattern of $\mathrm{Na}>\mathrm{Ca}>\mathrm{Mg}>\mathrm{K}$ and $\mathrm{HCO}_{3}>\mathrm{Cl}$ $>\mathrm{SO}_{4}$, a pattern which is an intermediate between fresh and sea water systems. The dominance of chloride over sulphate could probably be due to domestic activities resulting from household effluents, fertilizer use and other anthropogenic point sources. Trace metal levels were low suggesting low metal contamination of the river. However, the microbial quality of the river water was poor due to direct contamination by animal and human excreta and other activities such as swimming, washing of clothes, etc. The river water cannot be used for domestic purposes without any form of treatment.
\end{abstract}

\section{Introduction}

Water is super abundant on the planet as a whole, but fresh potable water is not always available at the right time or the right place for human or ecosystem use. The importance of water is underscored by the fact that many great civilizations in the past sprang up along or near water bodies. The development of water resources has often been used as a yardstick for socioeconomic and health status of many nations worldwide. However, pollution of waters often negates the benefits obtained from the development of these water resources.

With the ever-expanding population in the Densu basin in Ghana, there is the urgency for proper conservation and efficient utilization of freshwater bodies for sustainable development. The population pressures in the basin cause an acceleration of the pro-gressive deterioration of water quality because of increased domestic, municipal, agricultural and industrial activities, and effluent being discharged into water bodies and increase in environmental degradation resulting from urbanization and deforestation.

An impounded reservoir on the Densu river at Weija, a few kilometres before it discharges into the Atlantic Ocean, is an important source of water supply for the western part of the city of Accra. The major environmental concerns are erosion, siltation and pollution of the river, garbage and human wastes and excreta disposal, effluent from industries, motor garages and mechanical shops. Agricultural activities in the basin have caused considerable damage to the environment and polluted the river. Human contact and use of the water for bathing, washing, swimming, irrigation and gardening are intense in the basin. These situations have resulted in siltation, pollution and prevalence of water-associated diseases (e.g. bilharzia, enteric infections and intestinal worms) in the area. Industrial wastes from fruit processing factories, and other industries are discharged into the river.

Earlier study by Amuzu (1975) revealed that the Densu river water could be generally classified as good source of water supply along most of its stretches, though areas around Nsawam bridge fall into the poor water supply category. Ansa-Asare (1992) also revealed that areas around Suhum, Pakro and Suhyien were of poor water quality. Due to growing population 
densities, progressive industralisation and intensification of agricultural activities the Densu river is presently one of the most polluted rivers in the country (WRC, 2000). This paper aims at assessing the present water quality of the Densu river in relation to agricultural and other activities in the basin.

Study area

\section{Materials and methods}

The Densu river basin lies between latitude $5^{\circ} 30^{\prime} \mathrm{N}$ to $6^{\circ} 20^{\prime} \mathrm{N}$ and longitude $0^{\circ} 10^{\prime} \mathrm{W}$ to $0^{\circ}$ $35^{\prime} \mathrm{W}$ (Fig. 1). The river shares its catchment boundary with the Odaw and Volta basins to the east and north, respec-tively, the Birim basin in the northwest and the Ayensu and Okrudu in the west.

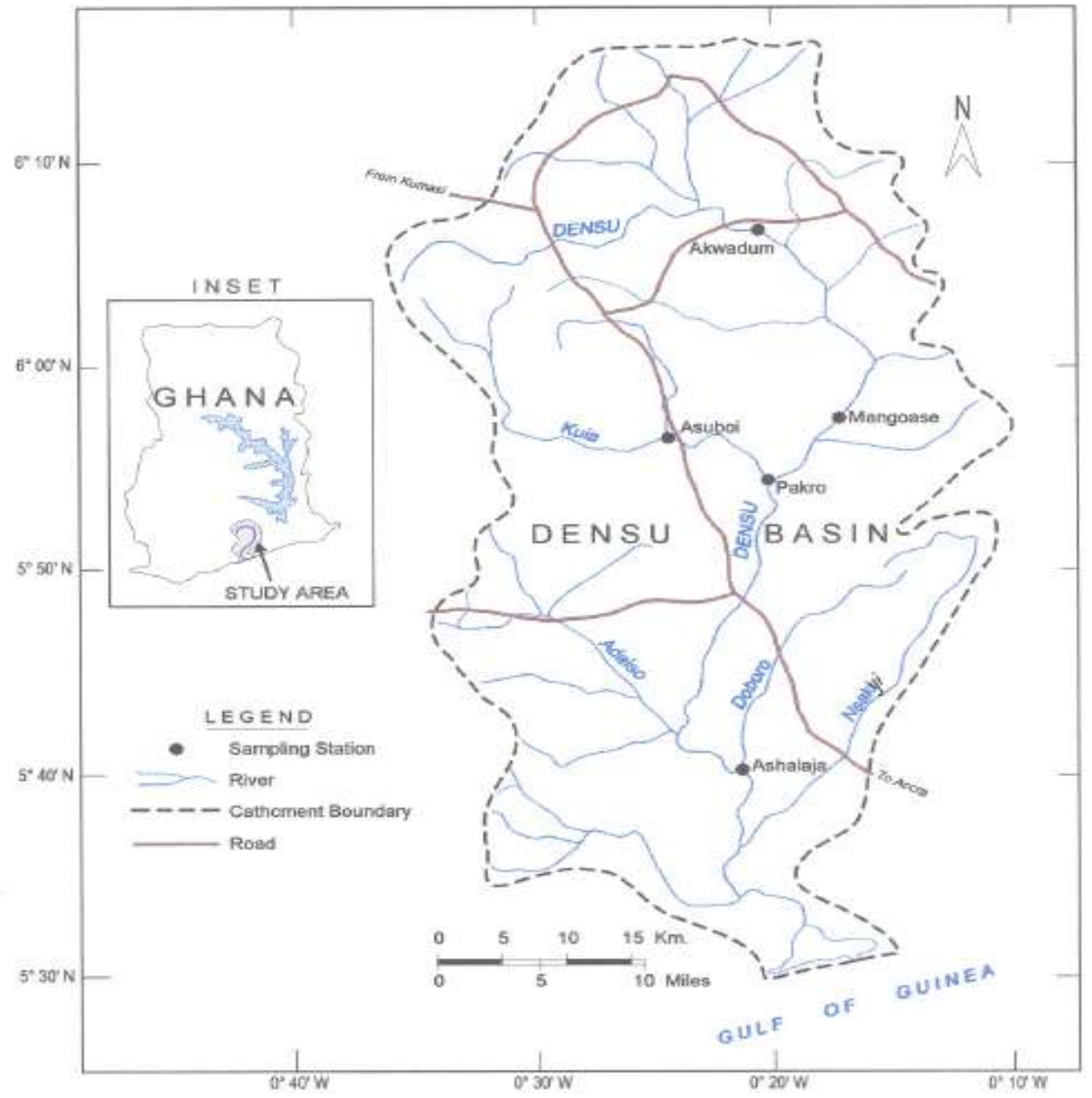

Figure 1: Location of Sampling Stations in the Densu Basin

The source of the Densu river is from the Atewa-Atwiredu mountain range near Kibi in the East Akyem District of the Eastern Region of Ghana. The river is about $116 \mathrm{~km}$ long with a catchment area of $2564 \mathrm{~km}^{2}$ covering nine administrative districts. The main tributaries include rivers Adeiso, Nsakyi, Dobro, and Kuia (Fig. 1). The Densu river enters the Weija reservoir, one 
of the two main sources of water supply for the city of Accra. The Weija reservoir discharges into Sakumo II lagoon which, subsequently, drains into the Gulf of Guinea near Bortianor to the west of Accra.

The basin falls under two distinct climatic zones. Both climatic zones are characterized by two rainfall regimes with different intensities (Dickson \& Benneh, 1980). The major rainy season extends from April/May to July. The minor one occurs between September and November. The mean annual rainfall varies from about $800 \mathrm{~mm}$ near the coast to about $1600 \mathrm{~mm}$ in the river source area. The mean annual temperature is about $27^{\circ} \mathrm{C}$, with March/April being the hottest (32 ${ }^{\circ} \mathrm{C}$ ) and August being the coldest month $\left(23{ }^{\circ} \mathrm{C}\right)$. Mainly crystalline rocks, comprising five formations, namely Birimian, Granites, Togo series, Dahomeyan and Accraian, underlie the basin. With the exception of Accraian, the rest are Precambrian. The dominant soils are ochrosols, with patches of gleisols and lithosols.

The economic activities in the catchment include cultivation of crops such as cocoa, maize, cassava, vegetables, pineapples and cocoyam as well as the raising of livestock and fishing. The communities around the river use the water extensively for drinking and other domestic purposes without prior treatment.

\section{Sampling and field work}

Five sampling stations were chosen based on accessibility and where hydrological stations have been established by the Hydrological Services Division of Ghana. These were Akwadum, Mangoase, Asuboi, Pakro and Ashalaja. Each station was sampled five times in a year, namely July, August, October, November, 2003 and March, 2004. The sampling covered both wet (April, May-July and September-October) and dry seasons (November, December, January-March) of the year for Ghana.

Surface water samples for physico-chemical analyses were collected mid-stream at depths 20 $30 \mathrm{~cm}$ directly into clean 1 litre plastic bottles. Temperature and $p \mathrm{H}$ were measured in situ, using a temperature probe and portable $p \mathrm{H}$ meter, Cyberscan $p \mathrm{H} 300$ series, respectively. For dissolved oxygen (DO) determinations, separate samples were collected into $300 \mathrm{ml}$ plain glass bottles and the DO fixed using the azide modification of Winkler's method. Samples for biological oxygen demand (BOD) were collected into dark glass bottles for incubation and subsequent DO determination. Samples for bacterio-logical analyses were collected into sterilized plain glass bottles. All samples were stored in an icebox at $4{ }^{\circ} \mathrm{C}$ and transported to the CSIR-Water Research Institute's laboratory in Accra for analyses.

\section{Laboratory analyses}

The physico-chemical parameters were determined according to procedures outlined in the Standard Methods for the Examina-tion of Water and Wastewater (APHA, 1998). Conductivity was measured with Cybersan 510 conductivity meter, and turbidity with a HACH $2100 \mathrm{P}$ Turbidimeter. Sodium and potassium were measured by flame emission photometry, trace metals by atomic absorption spectrophotometer, calcium and magnesium by EDTA titration, sulphate by the turbidimetric method, colour by colour comparator and chloride by argentometric tittration. Other analyses included alkalinity by strong acid titration method. Nutrients (nitrate-nitrogen and phosphate-phosphorous) were determined using Dionex-80 ion analyzer and ammonium by direct nesslerisation and spectrophoto-metric determination at $410 \mathrm{~nm}$. Fluoride by SPADNS method, total dissolved solids and suspended solids were measured gravimetri-cally after drying in an oven to a constant weight at $105^{\circ} \mathrm{C}$. Total and faecal coliforms were determined by membrane filtration method using M-Endo-Agar Les (Difco) at $37{ }^{\circ} \mathrm{C}$ and on MFC Agar at $44{ }^{\circ} \mathrm{C}$, respectively.

The results in $\mathrm{mg} / \mathrm{l}$ were converted into loads using mean discharges and concentrations measured. The formula used is outlined by Tilrem (1979) as: 


$$
\mathrm{L}=\mathrm{KCQ}_{\mathrm{w}} \text {, }
$$

where $\mathrm{L}=$ loads in $\mathrm{t} \mathrm{day}^{-1}, \mathrm{~K}=0.0864, \mathrm{C}=$ Concentration in $\mathrm{mg} / \mathrm{l}$, and $\mathrm{Qw}=$ Water discharge in $\mathrm{m}^{3} \mathrm{~s}^{-1}$.

The mean discharges over a 30-year period at the various stations in the Densu basin were used in the computation of the loads to $\mathrm{kg} \mathrm{day}^{-1}$ for BOD, nitrate, phosphate, sulphate, suspended solids and total dissolved solids. Pearson's rank correlation was also used to establish relations between parameters in the Densu basin. All tests were two-tailed. The analyses were executed by SPSS (version 12 for Windows, year 2003).

\section{Results and discussion}

A summary of the results of physico-chemical analyses and nutrient loads have been presented in Tables 1-4. Where possible, these values have been placed alongside natural background levels for tropical surface waters and WHO guideline values (Burton \& Liss, 1976; Jorgensen, 1979; Stumm \& Morgan, 1981; WHO, 1987).

TABLE 1

Mean $( \pm S D)$ of physical parameters of Densu basin

$\begin{array}{lccccc}\text { Parameter } & \text { Akwadum } & \text { Mangoase } & \text { Asuboi } & \text { Pakro } & \text { Ashalaja } \\ & \text { Mean } \pm S D & \text { Mean } \pm S D & \text { Mean } \pm S D & \text { Mean } \pm S D & \text { Mean } \pm S D \\ & & & & & \\ \text { Temperature }\left({ }^{\circ} \mathrm{C}\right) & 27.1 \pm 1.3 & 27.5 \pm 1.6 & 27.1 \pm 1.0 & 27.2 \pm 1.4 & 26.8 \pm 1.4 \\ p \mathrm{H} & 7.21 \pm 0.39 & 7.38 \pm 0.37 & 7.48 \pm 0.46 & 7.20 \pm 0.33 & 7.22 \pm 0.32 \\ \text { Colour }(\mathrm{Hz}) & 78.9 \pm 45.3 & 87.0 \pm 36.0 & 79.2 \pm 41.0 & 94.0 \pm 34.4 & 107 \pm 53.3 \\ \text { Turbidity }(\mathrm{NTU}) & 32.1 \pm 29.9 & 31.6 \pm 12.0 & 21.5 \pm 13.0 & 36.7 \pm 12.6 & 49.4 \pm 24.1 \\ \text { Cond. }(\mu \mathrm{S} / \mathrm{cm}) & 239 \pm 33.0 & 347 \pm 52.4 & 363 \pm 95.4 & 358 \pm 54.5 & 402 \pm 77.4 \\ \text { Discharge }\left(\mathrm{M}^{3} \mathrm{sec}^{-1}\right) & 2.29 & 2.85 & 0.69 & 8.10 & 12.31 \\ \text { DO }\left(\mathrm{Mgl}^{-1}\right) & 6.89 \pm 1.32 & 7.16 \pm 0.80 & 6.86 \pm 0.70 & 6.60 \pm 0.53 & 6.73 \pm 0.50 \\ \text { Hardness }\left(\mathrm{Mgl}^{-1}\right) & 92.4 \pm 16.8 & 97.6 \pm 19.0 & 111 \pm 16.9 & 91.2 \pm 11.0 & 93.6 \pm 9.0\end{array}$

SD - Standard deviation

TABLE 2

Mean loads of selected chemical parameters of Densu Basin $\left(\mathrm{kg} \mathrm{day}^{-1}\right)$

$\begin{array}{lrccccrr}\text { Stations } & \text { BOD } & \text { Nitrate } & \text { Phosphate } & \text { Ammonium } & \text { SS } & \text { TDS } & \text { Sulphate } \\ & & & & & & & \\ \text { Akwadum } & 543 & 49.4 & 27.7 & 81.0 & 2628 & 28058 & 1383 \\ \text { Mangoase } & 587 & 160 & 32.1 & 118 & 7274 & 49810 & 3008 \\ \text { Asuboi } & 141 & 15.4 & 11.3 & 16.6 & 1211 & 11633 & 683 \\ \text { Pakro } & 1714 & 371 & 112 & 408 & 32748 & 145549 & 10286 \\ \text { Ashalaja } & 2712 & 351 & 181 & 521 & 60943 & 239306 & 22548\end{array}$

TABLE 3

Mean concentration $( \pm S D)$ of trace metals in Densu basin $\left(m g l^{-1}\right)$

Stations

Akwadum

Mangoase

$\begin{array}{lllll}\begin{array}{l}\text { Fe } \\ \text { Mean } \pm S D\end{array} & \begin{array}{l}\text { Mn } \\ \text { Mean } \pm S D\end{array} & \text { Mean } \pm S D & \text { Mean } \pm S D & \begin{array}{l}\text { Mean } \pm S D \\ \end{array} \\ & & & & \\ 1.06 \pm 0.32 & 0.264 \pm 0.27 & 0.274 \pm 0.49 & 0.014 \pm 0.01 & <0.005 \\ 0.945 \pm 0.20 & 0.276 \pm 0.26 & 0.028 \pm 0.01 & 0.10 \pm 0.05 & 0.007 \pm 0.002\end{array}$




$\begin{array}{lllllc}\text { Asuboi } & 0.614 \pm 0.22 & 0.278 \pm 0.29 & 0.032 \pm 0.02 & 0.020 \pm 0.02 & 0.009 \pm 0.005 \\ \text { Pakro } & 1.19 \pm 0.46 & 0.337 \pm 0.28 & 0.034 \pm 0.02 & 0.099 \pm 0.09 & 0.030 \pm 0.05 \\ \text { Ashalaja } & 1.01 \pm 0.27 & 0.300 \pm 0.25 & 0.030 \pm 0.006 & 0.054 \pm 0.07 & 0.039 \pm 0.05 \\ \text { Average } & 0.964 & 0.291 & 0.080 & 0.057 & 0.018 \\ \text { Ranges } & 0.614-1.19 & 0.264-0.337 & 0.028-0.274 & 0.014-0.10 & <0.005-0.039 \\ \text { Background levels } & 0.300 & 0.100 & 1.00 & 5.00 & 0.050 \\ \text { WHO limits } & 0.300 & 0.50 & 1.00 & 0.500 & 0.050 \\ \text { (for drinking water) } & & & & & \end{array}$

TABLE 4

Correlation matrix of $\mathrm{r}$-values of mean data for all sampling stations within the Densu Basin

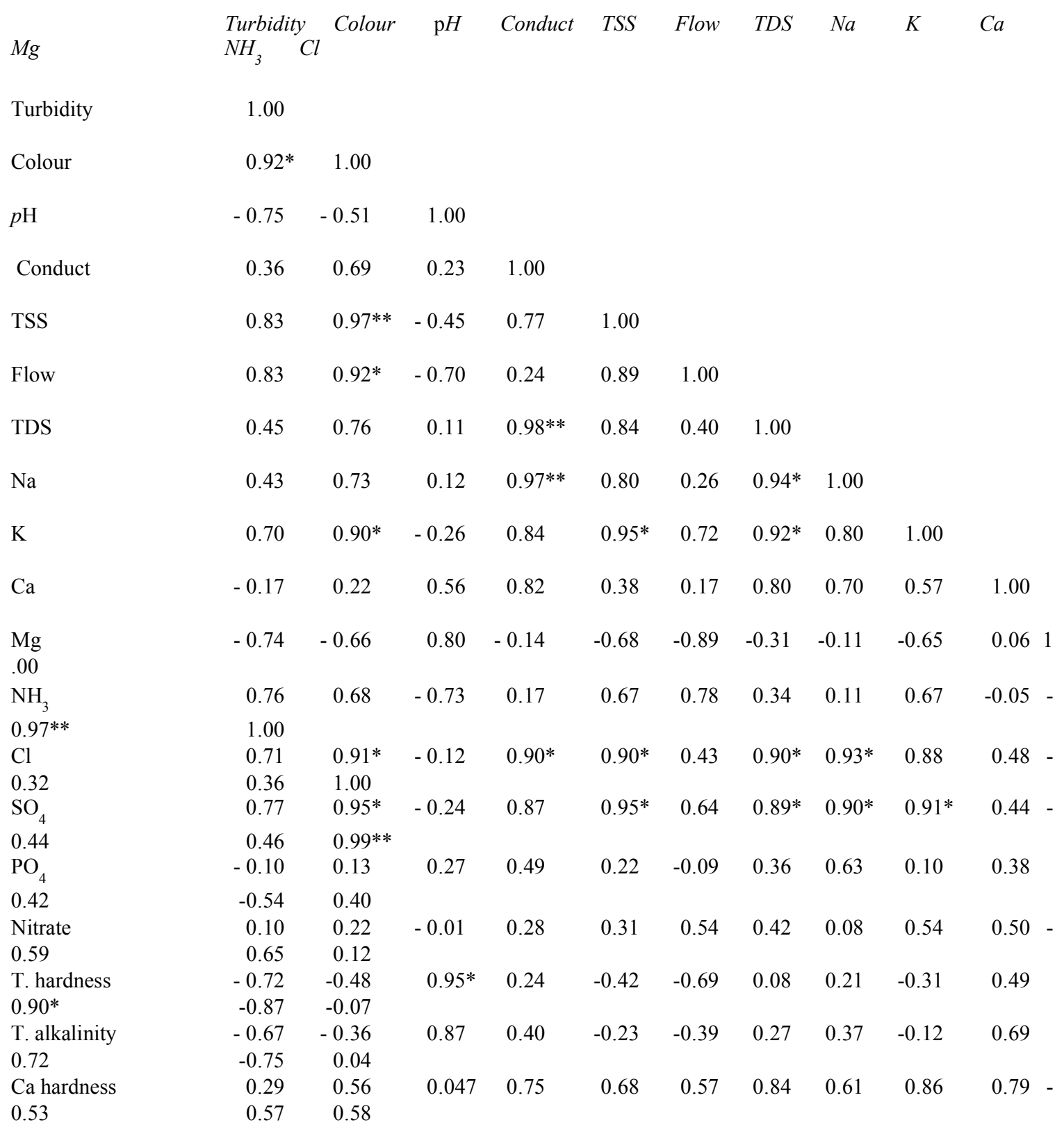




\begin{tabular}{|c|c|c|c|c|c|c|c|c|c|c|}
\hline Mg hardness & -0.74 & -0.69 & 0.77 & -0.20 & -0.72 & -0.91 & -0.37 & -0.17 & -0.69 & $-0.01 \quad 1$ \\
\hline $.00 * *$ & $-0.97 * *$ & -0.37 & & & & & & & & \\
\hline $\mathrm{F}$ & -0.34 & 0.02 & 0.79 & 0.69 & 0.13 & -0.16 & 0.65 & 0.54 & 0.37 & $0.92 *$ \\
\hline 0.29 & -0.21 & 0.34 & & & & & & & & \\
\hline $\mathrm{HCO}_{3}$ & -0.68 & -0.37 & 0.88 & 0.40 & -0.24 & -0.40 & 0.27 & 0.37 & -0.12 & 0.70 \\
\hline 0.72 & -0.75 & 0.03 & & & & & & & & \\
\hline \multirow[t]{2}{*}{ BOD } & 0.32 & -0.05 & -0.68 & -0.70 & -0.21 & -0.06 & -0.68 & -0.55 & -0.44 & $-0.98 * *$ \\
\hline & -0.15 & 0.11 & -0.33 & & & & & & & \\
\hline DO & -0.41 & -0.46 & 0.53 & -0.27 & -0.55 & -0.65 & -0.27 & -0.44 & -0.33 & -0.03 \\
\hline 0.35 & -0.16 & -0.38 & & & & & & & & \\
\hline Temperature & -0.53 & -0.49 & 0.36 & -0.23 & -0.40 & 0.12 & -0.15 & -0.45 & -0.15 & 0.27 \\
\hline $0.05^{1}$ & 0.11 & -0.51 & & & & & & & & \\
\hline
\end{tabular}

Note: Level of significance $* \mathrm{P}<0.05 * * \mathrm{P}<0.01$ (Pearson's rank correlation)

TABLE 4. (cont'd.)

$\mathrm{SO}_{4} \quad \mathrm{PO}_{4} \quad$ Nitrate $\quad$ T.hardness $\quad$ T. alkalinity $\quad$ Cahardness $M g$ hardness $\quad F$ $\mathrm{HCO}_{3} \mathrm{BOD}$ DO Temp.

Turbidity

Colour

$p \mathrm{H}$

Conduct

TSS

Flow

TDS

$\mathrm{Na}$

K

$\mathrm{Ca}$

$\mathrm{Mg}$

$\mathrm{NH}_{3}$

$\mathrm{Cl}$

$\mathrm{SO}_{4} \quad 1.00$

$\begin{array}{lll}\mathrm{PO}_{4} & 0.35 & 1.00\end{array}$

$\begin{array}{llll}\text { Nitrate } & 0.16 & -0.56 & 1.00\end{array}$

$\begin{array}{llll}\text { T. hardness } & -0.19 & 0.54 & -0.29\end{array}$

T. alkalinity

Ca hardness

$\begin{array}{lll}-0.06 & 0.66 & -0.15\end{array}$

$\begin{array}{rrr}0.61 & -0.06 & 0.83\end{array}$

$\begin{array}{llr}1.00 & & \\ 0.94^{*} & 1.00 & \\ -0.12 & 0.11 & 1.00 \\ 0.87 & 0.68 & -0.59 \\ 0.66 & 0.74 & 0.65 \\ 0.94 * & 1.00^{* *} & 0.12\end{array}$

1.00

$\begin{array}{lll}-0.48 & 0.39 & -0.61\end{array}$

$\begin{array}{lll}0.26 & 0.23 & 0.46\end{array}$

$0.94 *$

0.12

0.23

1.00

$\mathrm{HCO}_{3}$

$\begin{array}{lll}-0.07 & 0.64 & -0.13\end{array}$

0.68

0.75

1.00 


$\begin{array}{lrrrcccrr}\text { BOD } & -0.27 & -0.25 & -0.55 & -0.56 & -0.72 & -0.75 & -0.09 & - \\ 0.97^{*} & -0.73 & 1.00 & & & & & \\ \text { DO } & -0.44 & -0.63 & 0.29 & 0.29 & 0.04 & -0.06 & 0.35 & 0.33 \\ 0.07 & -0.17 & 1.00 & & & & & & \\ \text { Temperature } & -0.51 & -0.63 & 0.74 & 0.0 & 0.10 & 0.35 & -0.05 & 0.40 \\ 0.12 & -0.44 & 0.64 & 1.00 & & & & & \end{array}$

Note: Level of significance $* \mathrm{P}<0.05 * * \mathrm{P}<0.01$ (Pearson's rank correlation)

\section{Physico-chemical parameters}

The river water was neutral $(p \mathrm{H}$ range $7.20-7.48)$ and was unaffected by seasonal variation. The $p \mathrm{H}$ was within the range of 6.5-8.5 stipulated for drinking and domestic purposes (WHO, 1993). The EU also sets protection limits of $p \mathrm{H}$ from 6 to 9 for fisheries and aquatic life (Chapman, 1996). The $p \mathrm{H}$ obtained in the river waters was within these ranges. Based on these guidelines, the $p \mathrm{H}$ of the river water would not adversely affect its use for domestic and recreational purposes, and the aquatic ecosystem. The well buffered nature of the river water can be attributed to the fact that, normally, running waters are influenced by the nature of deposits over which they flow (Hynes, 1970). Water temperatures ranged from 26.8 to $27.5{ }^{\circ} \mathrm{C}$. These values are within the temperature ranges experienced in the basin.

Turbidity values ranged from 21.5 to 49.4 NTU. The background levels for turbidity vary from 0-5 NTU (WRC, 2003). These values grossly exceeded their background levels. The excessive turbidity in water causes problems with water purification processes such as flocculation and filtration, which may increase treatment cost (DWAF, 1989). Elevated turbid water is often associated with the possibility of micro-biological contamination as high turbidity makes it difficult to disinfect water properly (DWAF, 1998). The levels of turbidity recorded in this study were much higher than those reported for the same basin (range 2-14 NTU) by Amuzu (1975). Soil erosion and runoff from the catchments could be the source of high turbidity in the river water.

Electrical conductivity values varied between 237 and $402 \mu \mathrm{S} / \mathrm{cm}$. Ashalaja in the downstream recorded the highest conduc-tivity of $402 \mu \mathrm{S} / \mathrm{cm}$. Generally, the conduc-tivity of a river is lowest at the source of its catchments and, as it flows along the course of the river, it leaches ions from the soils and also picks up organic material from biota and its detritus (Ferrar, 1989). The average value of typical, unpolluted rivers is approximately $350 \mu \mathrm{S} / \mathrm{cm}$ (Koning \& Roos, 1999). Therefore, the parameter does not give cause for concern and it makes the water suitable for direct domestic use. When compared with conductivity of the Volta river at Kpong (range 62.0$77.5 \mu \mathrm{S} / \mathrm{cm}$ ) by Antwi \& Ofori-Danson (1993), the conductivities of River Densu were found to be higher. The fluctuations in electrical conductivity correlated positively with the total dissolved solids (TDS). Suspended solids (SS) and TDS are common indicators of polluted waters. TDS values ranged from 142 to $225 \mathrm{mgl}^{-1}$. These values were not high compared with WHO guideline value of $1000 \mathrm{mgl}^{-1}$. According to McCutheon et al. (1983), the palatability of water with TDS level less than $600 \mathrm{mgl}^{-1}$ is generally considered to be good whereas water with TDS greater than $1200 \mathrm{mgl}^{-1}$ becomes increasingly unpalatable.

Colour is an important physical property of water because of its implications for water supply, and the need to reduce it to acceptable levels by water treatment is highly recommended. Increase in the colour of water in reservoirs results in increases in treatment cost. Colour varied between $78.9-107 \mathrm{~Hz}$. These values are above $15 \mathrm{~Hz}$ which is WHO recommended limit for no risk. Colour in natural water usually results from the leaching of organic materials and is primarily the result of dissolved and colloidal humic substances, primarily humic and fulvic 
acids. Colour is also strongly influenced by the presence of iron and other metals, either as natural impurities or as corrosion products. Highly coloured water may be due to decaying vegetation.

The results shown in Table 1 indicate that the Densu river is moderately soft to slightly hard (range of hardness 91.2-111 $\mathrm{CaCO}_{3} \mathrm{mgl}^{-1}$ ) based on water hardness classification by Kunin (1972). The hardness is a function of the geology of the area with which the surface water is associated. The alkalinity values of the five stations varied between 84 and $136 \mathrm{mgl}^{-1} \mathrm{CaCO}_{3}$. Pristine surface waters are normally saturated with DO but such DO can be rapidly removed by the oxygen demand of organic wastes, and the manage-ment of DO provides a broad indicator of water quality (DFID, 1999). DO concentra-tions in unpolluted water are normally about 8-10 $\mathrm{mgl}^{-1}$ at $25{ }^{\circ} \mathrm{C}$ (DFID, 1999). Concentra-tions below $5.0 \mathrm{mgl}^{-1}$ adversely affect aquatic life. The concentration of DO in the river ranged from $6.60-7.16 \mathrm{mgl}^{-1}$ and, therefore, the river water is suitable for use of the aquatic ecosystem.

\section{Ionic dominance pattern}

Fig. 2 shows the estimated means and standard deviations of major elements (both cations and anions) for all stations and sampling occasions. The Densu basin exhibited an overall ionic dominance pattern of $\mathrm{Na}>\mathrm{Ca}>\mathrm{Mg}>\mathrm{K}$ and $\mathrm{HCO}_{3}>\mathrm{Cl}>\mathrm{SO}_{4}$. The ionic dominance of the Densu basin was in contrast with the ionic dominance pattern of $\mathrm{Ca}>\mathrm{Mg}>\mathrm{Na}>\mathrm{K}$ and $\mathrm{HCO}_{3}>$ $\mathrm{SO}_{4}>\mathrm{Cl}$ for fresh water and $\mathrm{Na}>\mathrm{Mg}>\mathrm{Ca}>\mathrm{K}$ and $\mathrm{Cl}>\mathrm{SO}_{4}>\mathrm{HCO}_{3}$ for sea water (Burton \& Liss, 1976). Thus, like most tropical fresh waters there is a dominance of $\mathrm{Ca}$ and $\mathrm{HCO}_{3}$ in the cationic and anionic components, respectively. A similar ionic dominance pattern was observed in the same basin by Biney (1987) and Ansa-Asare (1992). It is apparent that the dominance of chloride over sulphate could be due to the large amount of domestic wastes being discharged into the river waters. Studies conducted by Biney (1990) on characteristics of fresh water and coastal ecosystems in Ghana also confirmed this observation. Magnesium showed the highest variation within the sampling period. The high coefficient of variation (CV of 34.8-48.1\%) was due to the high level of domestic activities in the catchment.

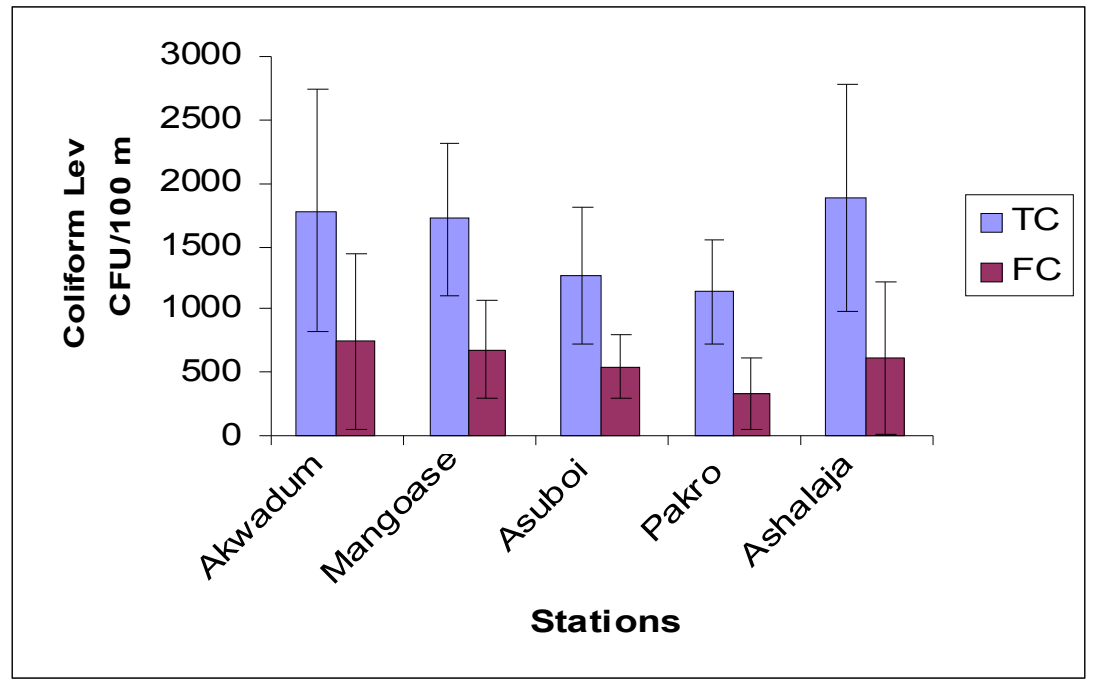

Fig. 2. Mean \pm SD of ions in the Densu Basin.

Nutrient loads 
The loads of all the nutrients showed positive correlation with the exception of phosphorous which showed negative relationship. This is because the major proportion of phosphorous transported to the aquatic environment from cultivated land is usually in particulate form through erosion (Sharpley et al., 1987). From Fig. 4, the dry season phosphorous was higher than the wet season, which is a confirmation of the above fact. Leaching transports relatively little soluble P, as $\mathrm{P}$ is strongly adsorbed on clay particles (Sibbesen, 1981).

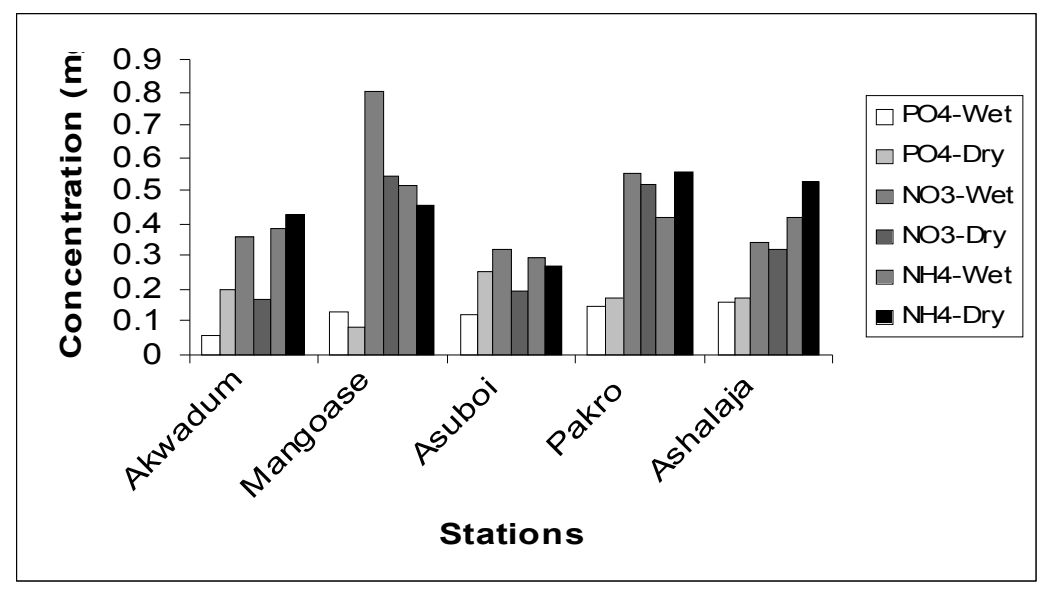

Fig. 3: Mean \pm SD of Total and Faecal Coliforms in the Densu Basin.

The loads of all the parameters increased with discharge (Table 2). Ashalaja recorded the highest loads followed by Pakro while Asuboi had the least loads. The exceptionally high loads observed for almost all the parameters at Ashalaja could be attributed to increased agricultural and domestic activities coupled with the high discharge in the area, as evidenced by the following loads. The nutrient loads observed at Ashalaja were nitrate ( $\left.351 \mathrm{~kg} \mathrm{day}^{-1}\right)$, ammonia $\left(521 \mathrm{~kg} \mathrm{day}^{-1}\right)$, and phosphate $(181 \mathrm{~kg}$ day $\left.^{-1}\right)$. Others were sulphate $\left(22,548 \mathrm{~kg} \mathrm{day}^{-1}\right)$, BOD $\left(2,712 \mathrm{~kg} \mathrm{day}^{-1}\right)$, SS $\left(60,943 \mathrm{~kg} \mathrm{day}^{-1}\right)$ and TDS $\left(239,306 \mathrm{~kg} \mathrm{day}^{-1}\right)$. Generally, when compared with the loads of Birim river basin reported by Ansa-Asare \& Asante (2000), the loads of Densu basin were relatively higher. This implied that there were more domestic and agricultural activities in the Densu catchment area.

\section{Trace metals}

The results of trace metal analysis in the water are presented in Table 3. Trace metals have been referred to as common pollutants, which are widely distributed in the environment with sources mainly from the weathering of minerals and soils (Marian, 1991; O'Neil, 1993). However, the level of these metals in the environ-ment has increased tremendously in the past decades as a result of inputs from human activities (Prater, 1975; Marian, 1991).

The mean concentrations of $\mathrm{Fe}$ in the water ranged from 0.614 to1.19 $\mathrm{mgl}^{-1}$. All the water points exceeded the background level and the WHO limit of $0.3 \mathrm{mgl}^{-1}$. The Densu basin is basically granite and analyses of rocks in Ghana (Kerbyson \& Schandorf, 1966) have shown that $\mathrm{Fe}_{2} \mathrm{O}_{3}$ composition in granite is about $2.8 \%$. This could primarily be the source of $\mathrm{Fe}$ in surface waters. It has also been demonstrated by Langanegger (1987) and Pelig-Ba (1989) that corrosive materials contribute significantly to the amount of $\mathrm{Fe}$ in the waters. Levels of $\mathrm{Mn}$ in the river water ranged from 0.276 to $0.337 \mathrm{mgl}^{-1}$. These levels exceeded the background level of $0.1 \mathrm{mgl}^{-1}$ probably as a result of weathering from rocks in the basin.

Levels of $\mathrm{Cu}$ in the river water varied between 0.028 and $0.220 \mathrm{mgl}^{-1}$. The background level and the WHO guideline for $\mathrm{Cu}$ in domestic water supply is $1.00 \mathrm{mgl}^{-1}$. The range obtained was lower than the set value, hence, adverse effects from domestic use are not expected as far as this 
parameter and the results obtained are concerned. The concentration of $\mathrm{Zn}$ ranged between 0.034 and $0.082 \mathrm{mgl}^{-1}$. The concentra-tions obtained were far below the background level of $0.50 \mathrm{mgl}^{-1}$. Therefore, there is no detrimental effect when the water is used for domestic purposes at the level obtained in this study. $\mathrm{Pb}$ levels ranged from $<0.005$ to $0.014 \mathrm{mgl}^{-1}$. The range obtained in the study fell below the background level, therefore, the water could be used for domestic and other purposes as far as this parameter is concerned.

The correlation matrix (Table 4) showed that flow and $\mathrm{NO}_{3}-\mathrm{N}$ concentrations were found to be positively correlated, with high $\mathrm{NO}_{3}-\mathrm{N}$ concentrations occurring in periods of high flow. The wet season $\mathrm{NO}_{3}-\mathrm{N}$ concentrations were, on the average, higher than that of the dry season (Fig. 4), which was a reflection of the fact that leaching is the most important mechanism for transporting $\mathrm{N}$ as nitrate from the terrestrial to the aquatic environment.

\section{Microbial water quality}

The results obtained for the microbial analysis are shown in Fig. 2. Historical data indicated that the microbial water quality of the Densu basin is poor (WRC, 2000). Total and faecal coliforms pollution was widespread, and the entire river basin as sampled is not suitable for domestic use without treatment. For agricultural purposes there is a possibility of contamination from vegetables and other crops eaten in their raw state.

The mean total coliforms ranged between 1136 and $1880 \mathrm{CFU} / 100 \mathrm{ml}$ while the faecal coliforms ranged between 336 and $739 \mathrm{CFU} / 100 \mathrm{ml}$. The results suggest that the general sanitary qualities of the water source, as indicated by total coliforms counts, were unacceptable. For water to be considered as no risk to human health, the faecal coliforms counts/100 ml should be zero (WHO, 1987). These results have indicated faecal pollution of the water sources, and imply that these water sources pose a serious health risk to consumers. The poor microbiological quality might be due to contamination caused by human activities and livestock. It is a common practice for people living along the river catchment to discharge their domestic and agricultural wastes as well as human excreta/wastes into rivers. In addition to using the river as a source of drinking water people use the source for bathing, washing of clothes and for recreational purposes such as swimming. Wild and domestic animals seeking drinking water can also contaminate the water through direct defaecation and urination.

\section{Conclusion}

The study has provided information about the water quality status of River Densu. The results indicated that $p \mathrm{H}$ and $\mathrm{DO}$ were all within their natural background levels of 6.5-8.5 and 5.0-7.0, respectively. The high turbidity observed in the basin is attributable to poor farming practices which result in large quantities of top soil ending up in the river after heavy rains. Turbidity indicates the presence of organic suspended material which promotes the growth of microorganisms (WRC, 1993). Nutrient loads in the Densu river were mainly from domestic, agricultural and commercial activities. Very high nutrient and BOD, SS, TDS loads were observed at Ashalaja due to high discharge rate and intensive agriculture.

The Densu basin exhibited a general ionic dominance pattern of $\mathrm{Na}>\mathrm{Ca}>\mathrm{Mg}>\mathrm{K}$ and $\mathrm{HCO}_{3}$ $>\mathrm{Cl}>\mathrm{SO}_{4}$. Both cationic and anionic patterns were intermediate between those of fresh and sea water but the dominance of chloride over sulphate could probably be due to domestic activities resulting from household effluents, fertilizer use and anthropogenic point sources. Fe and $\mathrm{Mn}$ levels exceeded their respective background levels. However, levels of other metals investigated $(\mathrm{Cu}, \mathrm{Zn}, \mathrm{Pb})$ were all below the natural background and WHO guideline levels. Hence there is no danger with respect to these metals. The microbiological quality of all the water sources was poor due to direct contamination by animal and human activities. 


\section{Recommendations}

The Densu river is used for a variety of purposes such as drinking, fishing, irrigation and other domestic purposes without prior treatment. For sustainable management of the water resource, the district assemblies should evolve sanitation programmes and propagate these through environmental education throughout the communities in the river catchments to prevent pollution of water bodies and consequent transmission of water-related diseases.

Farmers should be assisted in fertilizer application by agricultural extension officers of the Ministry of Food and Agriculture to avoid the incidence of high nutrient loads in surface waters. Since farmers in the basin use considerable volumes of pesticides, nematicides, fungicides and herbicides to control a variety of pests and diseases, pesticide residue analysis must be carried out to enhance better management of these agrochemicals.

\section{Acknowledgement}

The authors are grateful to Danida and the Ghana Government for providing funds for this study. The facilities provided by CSIR-Water Research Institute are, hereby, acknowledged.

\section{References}

Amuzu A. T. (1975). A Survey of the Water Quality of the River Densu. WRRI Technical Report, Accra, Ghana. 556.114 (667). $56 \mathrm{pp}$.

Ansa-Asare O. D. and Asante K. A. (2000). The Water Quality of Birim River in South-East of Ghana.West Afr. J. appl. Ecol. 1: 23-34.

Ansa-Asare O. D. (1992). Limno-chemical Characterization and Water Quality Assessment of River Densu. IAB Technical Report No. 132, Accra, Ghana. 40 pp.

Antwi L. A. K. and Ofori-Danson P. K. (1993). Limnology of a Tropical Reservoir (The Kpong Reservoir in Ghana). Trop. Ecol. 34: 75-87.

APHA (1998). Standard Methods for the Examination of Water and Wastewater, 20th edn. Washington, D.C.

Biney C. A. (1990). A Review of some Characteristics of Freshwater and Coastal Ecosystems in Ghana. Hydrobiologia 208: 45-53.

Biney C. A. (1987). Changes in the Chemistry of a Tropical Man-made Lake, the Densu Reservoir, During Five Years of Impoundment. Trop. Ecol. 28: 222-231.

Burton J. D and Liss P. S. (1976). Estuarine Chemistry. Academic Press, London. 229 pp.

Chapman D. (1996). Water Quality Assessment, 2nd edn. EPFN Spon, London.

DFID (1999). A Simple Methodology for Water Quality Monitoring. (G. R. Pearce, M. R. Chandhry and S. Ghulum, ed.) Department for international Development, Wallingford.

Dickson K. B. and Benneh G. (1980). A New Geography of Ghana. Longman, London.

DWAF (1998). Quality of Domestic Water Supplies. Assessment Guide, 2nd edn. Department of Water Affairs of Forestry, Department of Health and Water Research Commission, Pretoria, South Africa.

Ferrar A. A. (1989). Ecological Flow Requirements for South African Rivers. South African National Scientific Programmes, Report No. 162.

Hynes H. B. N. (1970). The Ecology of Running Waters. Liverpool University Press, Liverpool. 555 pp.

Jorgenson S. A. (1979). Handbook of Environmental Data and Ecological Parameters. Pergamons Press, Oxford. $1162 \mathrm{pp}$.

Kerbyson J. D. and Schandorf J. R.H. (1966). Chemical Analysis of Ghana rocks, Ores and Minerals, 1945-1965. Geol. Survey Bull. 42. Accra, Ghana.

Koning N. and Roos J. C. (1999). The Continued Influence of Organic Pollution on the Water Quality of the Turbid Modder River. Wat. S. Afr. 25(3): 285-292.

Kunin R. (1972). Water Softening by Ion Exchange. Proceedings Fourteenth Water Quality Conference, University of Illinois, Urbana, Il.

Langanegger O. (1987). Groundwater Quality, An important factor for selecting hand-pumps. BP 1850. 01, Abidjan, Cote d'Ivoire.

Marian E. (ed.) (1991). Metals and their Compounds in the Environment: Occurrence, Analysis and Biological Relevance. UCH, Weinheim-New York-Basel-Cambridge.

MacCutcheon S. C., Martin J. L. and Barnwell Jr T. O. (1983). Water Quality. In Handbook of Hydrology. McGraw-Hill Inc., New York.

O’Neil P. (1993). Environmental Chemistry. Chapman and Hall, London. 193 pp. 
Pelig-Ba K. B. (1989). A Report on an Investigation of Water Quality Problems on Borehole AP216 at Oyibi. Water Resources Research Institute, Accra, Ghana.

Prater B. E. (1975). The Metal Content and Characteristic of Steel Work Effluents Discharging to the Tees Estuary. Wat. Pollut. Control 74: 63-78.

Sharpley A. N., Smith S. J. and Naney J. W. (1987). The Environmental Impact of Agricultural Nitrogen and Phosphorus Use. J. Agric. Fd Chem. 35: 812-817.

Sibbesen E. (1981). Some New Equations to Describe Phosphate Sorption by Soils. J. Soil Sci. 32: 67-74.

Stumm W. and Morgan, J. J. (1981). Aquatic Chemistry. Willey, New York. 780 pp.

Tilrem Q. A. (1979). Sediment Transport in Streams, Sampling, Analysis and Computation, vol. 5. Manual on Procedures in Operational Hydrology.

Water Research Commission (WRC) (1993). Guidelines on the Cost Effectiveness of Rural Water Supply and Sanitation Projects. Water Research Commission Report No. 231/1/93. Pretoria.

Water Resources Commission (WRC) (2000). Water Resources Management Problems, Identification, Analysis and Prioritization Study. CSIR-Water Research Institute, Accra, Ghana. 130 pp.

Water Resources Commission (WRC) (2003). Ghana Raw Water Criteria and Guidelines Series. Report Prepared for Ghana Water Resources Commission by CSIR-Water Research Institute. WRI/TR No. 556.114 COU WRI/CAR No. 133.

World Health Organisation (1993). Guidelines for Drinking Water Quality. World Health Organization, Geneva, Switzerland.

World Health Organisation (1987). Guideline for Drinking Water, vol. 1. Recommendations. WHO, Geneva. 